\title{
Effects of supplementation frequency on the ruminal fermentation and enteric methane production of beef cattle grazing in tropical pastures
}

\author{
Roberta Carrilho Canesin ${ }^{1}$, Telma Teresinha Berchielli ${ }^{1}$, Juliana Duarte Messana ${ }^{1}$, \\ Fernando Baldi ${ }^{1}$, Alexandre Vaz Pires ${ }^{2}$, Rosa Toyoko Shiraishi Frighetto ${ }^{3}$, Giovani Fiorentini ${ }^{1}$, \\ Ricardo Andrade Reis ${ }^{1}$
}

\footnotetext{
Departamento de Zootecnia, Universidade Estadual Paulista "Júlio de Mesquita Filho", Jaboticabal, SP, Brasil.

2 Departamento de Zootecnia, Escola Superior de Agricultura "Luiz de Queiroz", Piracicaba, SP, Brasil.

${ }^{3}$ Embrapa Meio Ambiente, Jaguariúna, SP, Brasil.
}

\begin{abstract}
The objective of this study was to evaluate the characteristics of ruminal fermentation and enteric methane production in beef cattle subjected to different supplementation frequencies while grazing on Brachiaria brizantha cv. Marandu pastures. Nine cattle $(325 \pm 65.7 \mathrm{~kg} \mathrm{BW})$ fitted with ruminal and duodenal cannulas were used in the ruminal fermentation study, and 12 cattle $(399 \pm 32.6 \mathrm{~kg} \mathrm{BW})$ were used in the enteric methane production study. The treatments included supplementation once daily, supplementation once daily except Saturdays and Sundays, or supplementation on alternate days. The supplementation was equivalent to $10 \mathrm{~g} \mathrm{~kg}^{-1} \mathrm{BW}$ day ${ }^{-1}$ for all treatments. The design employed was completely randomized with three treatments and three replications. When all supplements were provided (day 1), no effects of supplementation frequency were observed on ruminal $\mathrm{pH}$; concentration of $\mathrm{NH}_{3}-\mathrm{N}$; concentration of acetic, propionic, or butyric acids; or total volatile fatty acids (VFA), but there were month effects. During the day on which only daily supplements were provided (day 2), significant differences were observed only on the molar concentration of acetic acid and total VFA; and month effects were noted on all variables. No significant differences were observed in ruminal fluid volume, dilution rate, $\mathrm{N}$ intake, bacterial $\mathrm{N}$ synthesis and enteric methane production among the studied supplementation frequencies. Differences were observed in the enteric methane production in the different months, with $85 \mathrm{~g} \mathrm{~kg}^{-1}$ of gross energy intake observed in September and $123 \mathrm{~g} \mathrm{~kg}^{-1}$ of gross energy intake observed in November. Lower supplementation frequency is a good option to lower labor costs with little or no consequences on ruminal fermentation characteristics and enteric methane production.
\end{abstract}

Key Words: bacterial $\mathrm{N}$ synthesis, $\mathrm{n}$-alkane, nutrient intake, ruminal methane, tropical pasture, volatile fatty acids

\section{Introduction}

In tropical regions, bovine herds mainly graze pastures in which quantitative and qualitative production is distributed in two distinct periods: a rainy and hot season and a dry and cold season. Therefore, it is necessary to promote supplementation, which is used to increase the intake and digestibility of forage in addition to being convenient in a technical-economical aspect. Consequently, the less frequent administration of supplements to animal grazing pastures, which is due to the search for a more intense rationalization of the labor force and a reduction of costs with supplementation, is a possibility that can be exploited in production systems as long as it does not impair animal performance.

Received March 16, 2014 and accepted September 4, 2014

Corresponding author: betacanesin@hotmail.com

http://dx.doi.org/10.1590/S1516-35982014001100005

Copyright (c) 2014 Sociedade Brasileira de Zootecnia. This is an Open Access article distributed under the terms of the Creative Commons Attribution Non-Commercial License, which permits unrestricted non-commercial use, distribution, and reproduction in any medium, provided the original work is properly cited.
Typically, when the supplementation frequency decreases, the amount of supplement supplied per week remains the same and the amount supplied per supplementation event is increased. Additionally, infrequent supplementation significantly alters microbial populations. For example, when a large dose of supplemental protein was provided, there was a lag in the ruminal degradation of the supplemental protein due to the inadequate protein fermentation caused by significant changes in the microbial population (Farmer et al., 2004). Data from the literature (Wickersham et al., 2008; Morais et al., 2009; Drewnoski and Poore, 2012) demonstrate that ruminants that are fed low-quality forage and are infrequently supplemented are capable of maintaining their performance, microbial efficiency, efficiency in utilizing dry matter, and nutrient intake compared with animals supplemented on a daily basis.

Animals receiving low-quality feed can lose approximately $12 \%$ of their gross energy in the form of $\mathrm{CH}_{4}$ (Johnson and Johnson, 1995). Recent studies designed to quantify and reduce methane emissions by ruminants have been conducted (Pelve et al., 2012). However, 
studies evaluating the effect of supplementation frequency on enteric methane production by zebu cattle in tropical pastures are rare. The objective of this study was to evaluate the effects of supplementation frequency (once daily; once daily except Saturdays and Sundays; or on alternate days) on the ruminal fermentation characteristics and enteric methane production of beef cattle grazing on Brachiaria brizantha $\mathrm{cv}$. Marandu pastures.

\section{Material and Methods}

The experiment was conducted at Faculdade de Ciências Agrárias e Veterinárias, Universidade Estadual de São Paulo, located in Jaboticabal/SP, Brazil. Nine Nellore steers with an average weight of $325 \pm 65.7 \mathrm{~kg} \mathrm{BW}$ and fitted with ruminal and duodenal cannulas were used to determine the ruminal parameters. These steers were distributed with 27 other steers (without cannulas) of the same breed and similar body weight in nine Brachiaria brizantha cv. Marandu paddocks of two hectares each under a continuous stocking grazing system. Of these 27 Nellore steers, 12 steers $(399 \pm 32.6 \mathrm{~kg} \mathrm{BW})$ were used to determine enteric methane production. Three paddocks were assigned to each treatment. Ruminal parameters were measured in August and October, and enteric methane emissions were measured in September and November of 2006.

The experimental protocol was approved by the Animal Ethics Committee of the Faculty of Agricultural and Veterinary Sciences, Universidade Estadual de São Paulo, Jaboticabal Campus (no. 021611/09). A completely randomized design was employed with three treatments (supplementation frequencies) and three replications (paddocks). Treatments were based on supplementation frequency, with the supplement fed at $08.00 \mathrm{~h}$ in troughs placed in the paddocks once daily (OD); once daily except Saturdays and Sundays (SS); or on alternate days (AD) at 10,14 , and $20 \mathrm{~g} \mathrm{~kg}^{-1} \mathrm{BW}$ day $^{-1}$, respectively (equivalent to $10 \mathrm{~g} \mathrm{~kg}^{-1} \mathrm{BW}$ day $^{-1}$ for all three treatments). Initially, the supplement was formulated to provide a minimum of $12 \% \mathrm{CP}$ in the dietary DM for requirements of microbial efficiency (NRC, 1984), assuming the low CP of the available forage during the experimental period. Thus, the supplement was formulated to contain $250 \mathrm{~g} \mathrm{~kg}^{-1} \mathrm{CP}$ in August and September and $280 \mathrm{~g} \mathrm{~kg}^{-1} \mathrm{CP}$ in October and November (Canesin et al., 2014) (Table 1).

The evaluations of pasture, ruminal parameters and enteric methane production were performed in both the dry (August and September) and rainy (October and November) seasons. The characteristics of structure, biomass availability and forage quality were assessed by throwing five $1 \mathrm{~m} \times 1 \mathrm{~m}$ metal squares randomly onto each paddock and cutting forage within them at the ground level. Half of the collected biomass was separated into green leaves, stems and dead material, and the rest was oven-dried $\left(55^{\circ} \mathrm{C}\right)$ for chemical composition and alkane analysis (Table 2) (Morais et al., 2009; Canesin et al., 2014; Morais et al., 2014).

Twenty-seven animals were chosen for estimating total dry matter intake (DMI), nine less-reactive animals from each treatment (three animals from each paddock; two animals without cannula and one cannulated) in August and September using the n-alkanes technique. Feces samples were collected directly from the rectum of each animal twice daily (at 07.00 and $17.00 \mathrm{~h}$ ) for five consecutive days and frozen at $-20{ }^{\circ} \mathrm{C}$ for analysis of n-alkane concentrations. At the end of each period, composite samples were formed for each animal based on the dry mass of the samples. The DMI

Table 1 - Centesimal composition (as is) and chemical composition of ingredients of the supplement

\begin{tabular}{|c|c|c|c|}
\hline & \multicolumn{3}{|c|}{ Supplement ingredients ${ }^{1}$} \\
\hline & Citrus pulp & Cottonseed meal & Urea \\
\hline \multicolumn{4}{|l|}{ Proportions, $\mathrm{g} \mathrm{kg}^{-1}$} \\
\hline August & 700 & 275 & 25 \\
\hline September & 700 & 275 & 25 \\
\hline October & 620 & 355 & 25 \\
\hline November & 620 & 355 & 25 \\
\hline \multicolumn{4}{|l|}{ Chemical composition } \\
\hline Dry matter, $\mathrm{g} \mathrm{kg}^{-1}$ & 896 & 907 & ND \\
\hline Organic matter, $\mathrm{g} \mathrm{kg}^{-1} \mathrm{DM}$ & 932 & 933 & ND \\
\hline Ash, $\mathrm{g} \mathrm{kg}^{-1} \mathrm{DM}$ & 68 & 67 & ND \\
\hline Crude protein, $\mathrm{g} \mathrm{kg}^{-1} \mathrm{DM}$ & 70 & 476 & 2,800 \\
\hline Neutral detergent fiber, $\mathrm{g} \mathrm{kg}^{-1} \mathrm{DM}$ & 222 & 340 & ND \\
\hline Acid detergent fiber, $\mathrm{g} \mathrm{kg}^{-1} \mathrm{DM}$ & 168 & 205 & ND \\
\hline Ether extract, $\mathrm{g} \mathrm{kg}^{-1} \mathrm{DM}$ & 25 & 14 & ND \\
\hline Gross energy, Mcal kg-1 DM & 3.74 & 4.35 & ND \\
\hline
\end{tabular}

ND - not defined.

${ }^{1}$ Plus $2 \mathrm{~g} \mathrm{~kg}^{-1}$ mineral supplement: $\mathrm{Ca}-155 \mathrm{~g} \mathrm{~kg}^{-1} ; \mathrm{P}-80 \mathrm{~g} \mathrm{~kg}^{-1} ; \mathrm{Mg}-10 \mathrm{~g} \mathrm{~kg}^{-1} ; \mathrm{S}-40 \mathrm{~g} \mathrm{~kg}^{-1} ; \mathrm{Na}^{-} 130 \mathrm{~g} \mathrm{~kg}^{-1} ; \mathrm{Cu}^{-1,350 \text { mg kg}}{ }^{-1} ; \mathrm{Mn}^{-} 1,040 \mathrm{mg} \mathrm{kg}{ }^{-1} ; \mathrm{Zn}-5,000 \mathrm{mg} \mathrm{kg}^{-1}$; I - $100 \mathrm{mg} \mathrm{kg}^{-1}$; Co - $80 \mathrm{mg} \mathrm{kg} \mathrm{k}^{-1}$; Se - $26 \mathrm{mg} \mathrm{kg}{ }^{-1}$; F (max.) - $800 \mathrm{mg} \mathrm{kg}^{-1}$. 
was estimated using the profile of alkanes from the dietary components (green leaves, stems and dead material) and supplement, reducing the squared differences between fecal concentrations of each alkane corrected for its relative fecal recovery and the theoretical proportions of each alkane in the feces (Dove and Moore, 1995; Dove et al., 1999).

Samples of ruminal fluid were collected during two consecutive days such that all animals were supplemented on the first sampling day (day 1); the OD animals received supplements, while AD and SS animals were not supplemented on the second day (day 2). The sampling times were at $08.00 \mathrm{~h}$ (before supplementation) and 2, 4, 6, 8 and $10 \mathrm{~h}$ after supplementation. The $\mathrm{pH}$ of ruminal fluid was immediately determined using a digital $\mathrm{pH}$ meter (ORION 710A, Boston, MA). The sample was then fractionated into two portions for VFA and ammonia nitrogen analyses. Rumen content $(3 \mathrm{~L})$ was collected from each animal and manually homogenized with saline solution $(1 \mathrm{~L})$ and subsequent centrifuged for isolation of ruminal bacteria.

The duodenal digesta were sampled for four days, in which the AD and SS animals received supplementation for two days and did not receive supplementation on the other two days. The collection occurred at $12.00 \mathrm{~h}$ and $16.00 \mathrm{~h}$ on the first day and at $10.00 \mathrm{~h}, 14.00 \mathrm{~h}$ and $18.00 \mathrm{~h}$ on the second day. The same arrangement was followed for the collections performed on days without supplementation in the $\mathrm{AD}$ and SS treatments. The procedure allowed for sampling at $10 \mathrm{~h}$ after supplementation at $2 \mathrm{~h}$ intervals.

Ruminal $\mathrm{CH}_{4}$ was measured in 12 animals (4 animals/ treatment) for six consecutive days over a period of $24 \mathrm{~h}$ in September and November with 15 prior adaptation days, using the sulfur hexafluoride $\left(\mathrm{SF}_{6}\right)$ tracer gas technique as described by Johnson and Johnson (1995) and adapted by Primavesi et al. (2004a).

Samples of forage, supplement and feces were milled through a $1 \mathrm{~mm}$ sieve to estimate the intake. Next, $0.5 \mathrm{~g}$ of the samples was weighed into $200 \times 20$-mm-thick-walled screw-topped Pyrex test-tubes containing $100 \mathrm{mg}$ of internal standard (a solution of heptane containing $1 \mathrm{mg} / \mathrm{g}$ of $\mathrm{C}_{22}$ and $\mathrm{C}_{34}$ ). Then, an extraction of the n-alkanes was performed by following the technique described by Mayes et al. (1986) and using the modifications suggested by Keli et al. (2008). An alkane analysis was performed through in Agilent 6890 gas chromatography instrument fitted with an automatic injector and a flame ionization detector. The detector response factors for individual n-alkanes were determined by injecting a standard n-alkane mixture $\left(\mathrm{C}_{21}-\mathrm{C}_{36}\right.$ inclusive $)$ onto the chromatograph after every eight sample extracts. The dry matter intake (DMI) of forage was calculated based on a pair of alkanes, $\mathrm{C}_{31}$ (naturally present in the diet) and $\mathrm{C}_{32}$ (dosed) (Mayes et al., 1986). The total DM intake was estimated as the forage DM intake (estimated by the n-alkane technique) + the individual amount of supplement offered, as described by Morais et al. (2014). The flow of DM ( $\left.\mathrm{kg} \mathrm{DM} \mathrm{day}{ }^{-1}\right)$ was estimated as the DM intake of $\mathrm{C}_{31}\left(\mathrm{mg} \mathrm{C}_{31}\right.$ day $\left.^{-1}\right)$ divided by the concentration of the $\mathrm{C}_{31}$ alkane in the duodenal digesta $\left(\mathrm{mg} \mathrm{kg}^{-1} \mathrm{DM}\right)$.

The concentrations of ammonia nitrogen were obtained after distillation with $\mathrm{KOH} 2 \mathrm{~N}$, according to the technique described by Fenner (1965), which was adapted for use in Kjeldahl distillation. The ruminal fluid samples were centrifuged at $11,000 \times \mathrm{g}$ at $4{ }^{\circ} \mathrm{C}$ for $20 \mathrm{~min}$; an aliquot was used for the determination of VFA according to the method of Palmquist and Conrad (1971). Co-EDTA was

Table 2 - Initial body weight of animals $(\mathrm{BW}, \mathrm{n}=36)$, biomass availability and forage chemical composition $(\mathrm{n}=9)$

\begin{tabular}{|c|c|c|c|c|}
\hline & \multicolumn{4}{|c|}{ Forage } \\
\hline & August & September & October & November \\
\hline Body weight, kg & 357 & 361 & 367 & 392 \\
\hline Total biomass, t DM ha ${ }^{-1}$ & 3.8 & 3.8 & 4.1 & 4.8 \\
\hline Total biomass, $\mathrm{kg} 100 \mathrm{~kg}^{-1} \mathrm{BW}$ & 18.9 & 18.8 & 19.9 & 21.7 \\
\hline Green leaves, $\mathrm{g} \mathrm{kg}^{-1}$ & 66 & 90 & 312 & 324 \\
\hline Green leaves, kg $100 \mathrm{~kg}^{-1} \mathrm{BW}$ & 12 & 17 & 63 & 70 \\
\hline Stems, $\mathrm{g} \mathrm{kg}^{-1}$ & 693 & 64.8 & 498 & 501 \\
\hline Dead material, $\mathrm{g} \mathrm{kg}^{-1}$ & 241 & 261 & 190 & 175 \\
\hline \multicolumn{5}{|l|}{ Chemical composition } \\
\hline Dry matter, $\mathrm{g} \mathrm{kg}^{-1}$ & 694 & 641 & 426 & 438 \\
\hline Organic matter, $\mathrm{g} \mathrm{kg}^{-1} \mathrm{DM}$ & 940 & 939 & 929 & 927 \\
\hline Ash, $\mathrm{g} \mathrm{kg}^{-1} \mathrm{DM}$ & 60 & 61 & 71 & 73 \\
\hline Crude protein, $\mathrm{g} \mathrm{kg}^{-1} \mathrm{DM}$ & 27 & 30 & 48 & 43 \\
\hline Neutral detergent fiber, $\mathrm{g} \mathrm{kg}^{-1} \mathrm{DM}$ & 789 & 752 & 742 & 696 \\
\hline Acid detergent fiber, $\mathrm{g} \mathrm{kg}^{-1} \mathrm{DM}$ & 470 & 460 & 427 & 403 \\
\hline Ether extract, $\mathrm{g} \mathrm{kg}^{-1} \mathrm{DM}$ & 14 & 13 & 14 & 11 \\
\hline Gross energy, Mcal kg-1 DM & ND & 3.34 & ND & 3.93 \\
\hline
\end{tabular}

ND - not detected. 
used to determine the ruminal volume and dilution rate by infusion through a cannula directly into the rumen of each animal in a single $30 \mathrm{~g}$ dose diluted into $300 \mathrm{~mL}$ of distilled water one hour after feed administration, according to the method of Udén et al. (1980). The ruminal fluid was sampled before the infusion and then every two hours until $12 \mathrm{~h}$ after the Co-EDTA administration. To determine the Co-EDTA concentration, the ruminal fluid samples were centrifuged at $500 \times g$ for $15 \mathrm{~min}$ after thawing, and a supernatant reading was performed using an atomic absorption spectrometer (VARIAN 220 FS, Mulgrave, AUS). The ruminal volume and dilution rate were estimated by regressing the natural logarithm of the cobalt concentration against the sampling time, as described by Warner and Stacy (1968).

The duodenal digesta samples were previously ovendried using a forced air-circulation oven at $55{ }^{\circ} \mathrm{C}$ for $96 \mathrm{~h}$ immediately after collection. The dried samples were ground through a Wiley mill (1 mm screen). A compound sample was created for each animal in each collection period based on the dry weight of each subsample. The isolation of bacteria from the ruminal digesta samples was achieved using differential centrifugation procedures (Cecava et al., 1990), and after isolation, the samples were lyophilized (Thermo Electron Corporation, Modulyo D, Milford, MA). Purines were determined from the $\mathrm{N}$ purines:total bacterial $\mathrm{N}$ ratios in these and the duodenal digesta samples for later estimation of bacterial $\mathrm{N}$ flux using the procedure described by Zinn and Owens (1986) with the modifications proposed by Ushida et al. (1985). $\mathrm{CH}_{4}$ flux produced by animals was calculated in relation to the $\mathrm{SF}_{6}$ tracer gas flux from a permeation capsule lodged in the rumen minus the basal $\mathrm{CH}_{4}$ concentrations in the air (Westberg et al., 1998).

Dry matter (DM), crude protein (CP) and ash contents were analyzed according to AOAC (1990), and the gross energy was determined using an adiabatic bomb calorimeter (PARR Instrument Company 6300, Illinois, USA). The levels of neutral detergent fiber (NDF) and acid detergent fiber (ADF) were analyzed using the methods of Mertens (2002) and Van Soest and Robertson (1985), respectively, using samples digested in detergent solution in filter bags
$\left(\mathrm{F} 57-\mathrm{Ankom}^{\circledR}\right.$ ) for $40 \mathrm{~min}$ in an autoclave at $110^{\circ} \mathrm{C}$ and $0.5 \mathrm{~atm}$, as described by Senger et al. (2008). Heat-stable amylase and sodium sulfite were used to determine the NDF content in the supplements; however, this method was not used in the forage sample analyses.

All of the data were analyzed using a repeated-measures analysis of variance, with time as the repeated factor, using the PROC MIXED procedure of SAS (Statistical Analysis System, version 9.0) with the repeated option. In the evaluation of $\mathrm{pH}$, ammonia $\mathrm{N}$ and VFA variables, the data were analyzed with a model including the effect of the supplementation frequency, the month of evaluation, the collection timetables included in the month and the respective interactions. The evaluation of the day effect (day 1 and day 2) was analyzed separately because of the proposal to evaluate the differences of the parameters during each day.

The model that included the effects of the supplementation frequency, the month of evaluation, and the respective interactions was used in the nutrient intake, ruminal fluid volume, dilution rate, bacterial $\mathrm{N}$ synthesis and enteric methane production analyses. Different structures of variance and covariance matrices for the residue were tested to determine the structure that best fits each variable. The matrices were chosen according to AIC (Akaike's Information Criteria) and BIC (Bayesian Information Criteria). The adjusted means were compared using the Tukey test and probabilities $<0.05$ were considered significant.

\section{Results}

Supplementation frequency did not affect the forage and total dry matter intakes (DMI) $(\mathrm{P}>0.05)$ (Table 3). Nevertheless, an effect of month was observed on forage and total DMI; moreover, there was no interactive effect of supplementation frequency $\times$ month on DM intake. On the day when all supplements were provided (day 1), supplementation frequency $\times$ month interaction was observed on ruminal $\mathrm{pH}$. Month effects were observed, but the molar concentration of acetate was similar in August and October (Table 4). As expected, there was a significant

Table 3 - Effect of the supplementation frequency on steers intake $(\mathrm{n}=9)$

\begin{tabular}{|c|c|c|c|c|c|c|c|c|c|c|}
\hline \multirow{2}{*}{ DMI, kg $100 \mathrm{~kg}^{-1} \mathrm{BW}$} & \multicolumn{3}{|c|}{ Supplementation frequency } & \multicolumn{3}{|c|}{ Months } & \multirow{2}{*}{ SEM } & \multicolumn{3}{|c|}{ P-value } \\
\hline & $\mathrm{AD}$ & SS & OD & August & September & November & & SF & M & $\mathrm{SF} \times \mathrm{M}$ \\
\hline Forage & 1.23 & 1.11 & 1.05 & $1.14 \mathrm{a}$ & $1.24 \mathrm{a}$ & $1.01 \mathrm{~b}$ & 0.06 & 0.10 & 0.01 & 0.76 \\
\hline Total $^{1}$ & 2.13 & 2.01 & 1.95 & $2.04 \mathrm{a}$ & $2.14 \mathrm{a}$ & $1.91 \mathrm{~b}$ & 0.06 & 0.11 & 0.01 & 0.73 \\
\hline
\end{tabular}

DMI - dry matter intake; AD - supplementation on alternate days; SS-supplementation once daily except Saturdays and Sundays; OD - supplementation once daily; SEM - standard error of the mean; SF - supplementation frequency; M - months; SF $\times$ M - supplementation frequency $\times$ month interaction.

$\mathrm{a}, \mathrm{b}$ - means followed by different letters are significantly different at $\mathrm{P}<0.05$.

${ }^{1}$ Forage intake plus total supplement provided to the animals. 
difference between the sampling times $(\mathrm{P}<0.05)$ (Figures 1 and 2); however, no effect of the supplementation frequency $\times$ time interaction was found.

The $\mathrm{pH}$ values were similar among the supplementation frequency treatments, and significant differences were observed at sampling time 0 (6.6), before supplementation, and from $2 \mathrm{~h}$ after supplementation (6.4) to $8 \mathrm{~h}$ after supplementation; however, the ruminal $\mathrm{pH}$ remained constant (6.1) (Figure 1). The $\mathrm{NH}_{3}-\mathrm{N}$ concentrations exhibited similar behavior among the supplementation frequency treatments on the day in which all supplements were provided (day 1), with an ammonia peak $2 \mathrm{~h}$ after

Table 4 - Effect of supplementation frequency on ruminal fermentation traits in the steers $(n=9)$

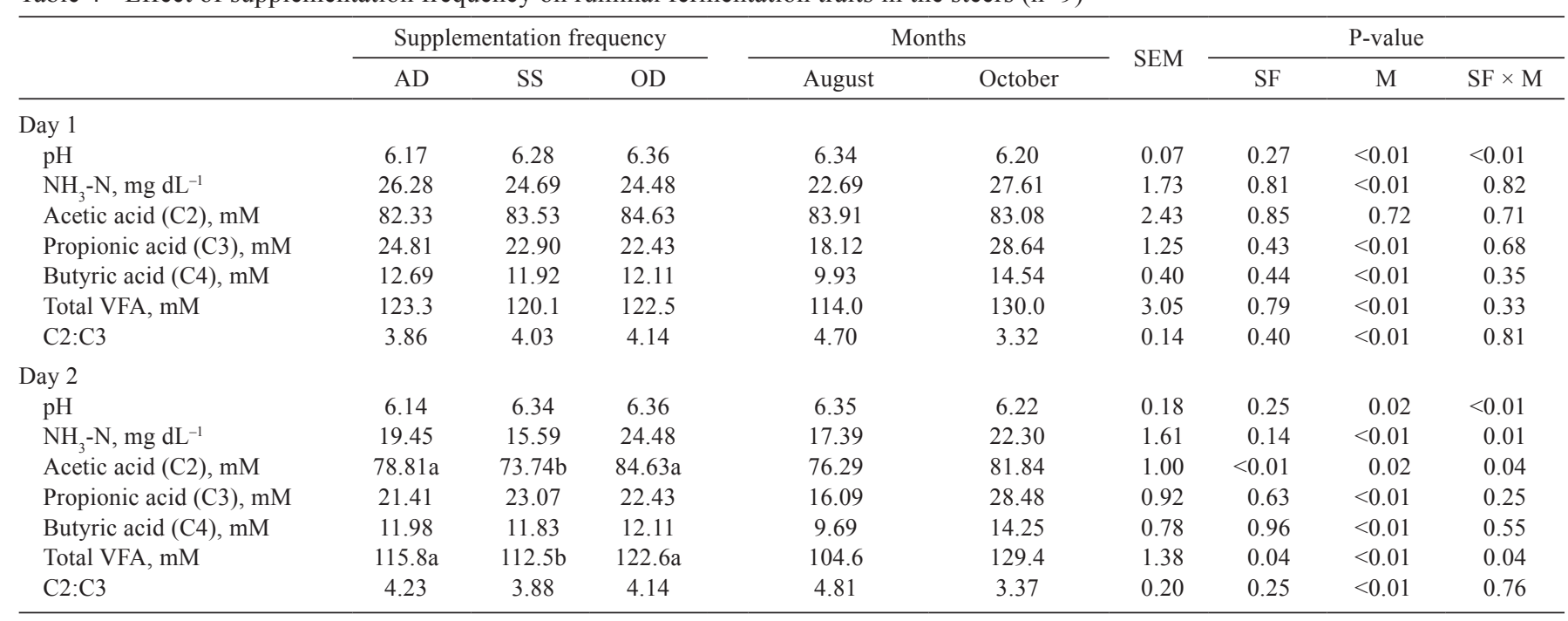

AD - supplementation on alternate days; SS - once daily except Saturdays and Sundays; OD - once daily; SEM - standard error of the mean; SF - supplementation frequency; $\mathrm{M}$ - months; $\mathrm{SF} \times \mathrm{M}$ - supplementation frequency $\times$ month interaction.

$\mathrm{a}, \mathrm{b}$ - means followed by different letters are significantly different at $\mathrm{P}<0.05$.

Day 1
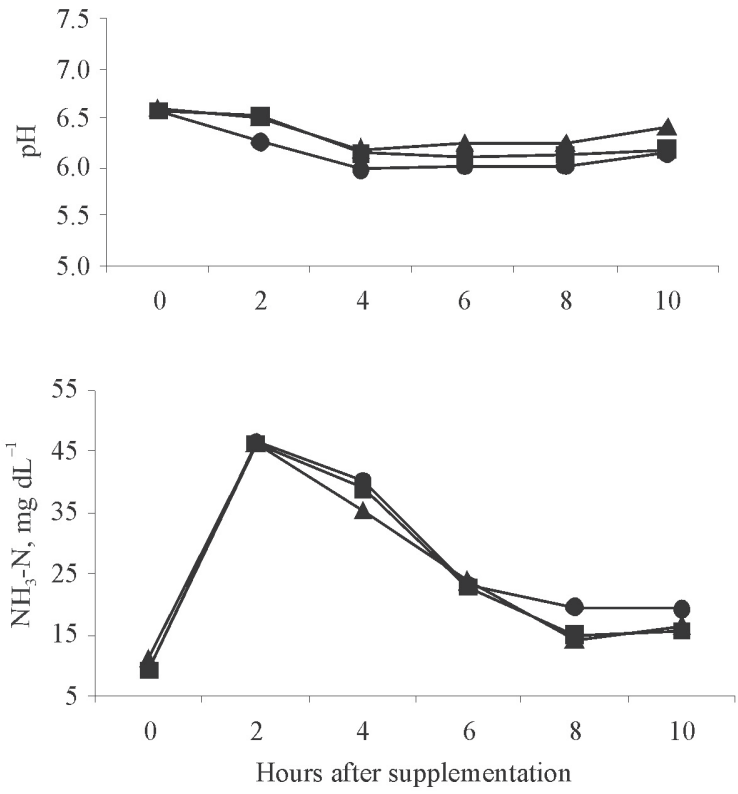

$\rightarrow \mathrm{AD} \rightarrow-\mathrm{SS} \rightarrow-\mathrm{OD}$
Day 2
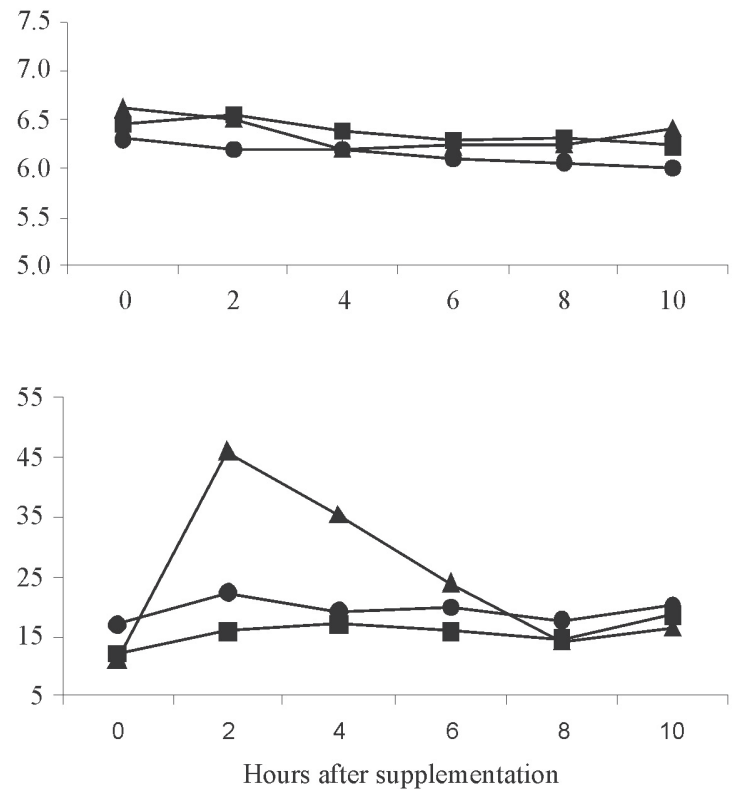

$\mathrm{AD} \rightarrow-\mathrm{SS} \rightarrow \mathrm{OD}$

Supplementation frequency: once daily (OD), once daily except Saturdays and Sundays (SS) and on alternate days (AD).

Figure 1 - Effect of supplementation frequency on steer ruminal $\mathrm{pH}$ and $\mathrm{NH}_{3}-\mathrm{N}$ on the day all supplements were provided (day 1) and on the day only daily supplements were provided (day 2 ). 


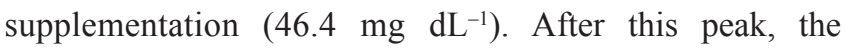
concentration of $\mathrm{NH}_{3}-\mathrm{N}$ decreased up to $8 \mathrm{~h}$ following supplementation and then remained constant (Figure 1).

The concentrations of VFA differed among the sampling times $(\mathrm{P}<0.05)$. Similar molar concentrations of acetic acid were observed at 0 and $2 \mathrm{~h}(78.8 \mathrm{mM}$ and $77.5 \mathrm{mM}$, respectively), and the concentration increased $4 \mathrm{~h}$ after supplementation. In contrast, the molar concentration of propionic acid was higher $2 \mathrm{~h}$ after supplementation
(26.8 $\mathrm{mM}$ ) because supplement intake increased the concentration of this acid. The highest concentrations of butyric acid were observed $2 \mathrm{~h}$ and $4 \mathrm{~h}$ after supplementation (13.3 $\mathrm{mM}$ and $13.5 \mathrm{mM}$, respectively); after $4 \mathrm{~h}$ following the supplementation the concentrations remained constant. A linear increase in the concentration of total VFA with increased sampling time was noted (Figure 2). On the day when only daily supplements were provided (day 2), significant differences were observed only in the molar
Day 1
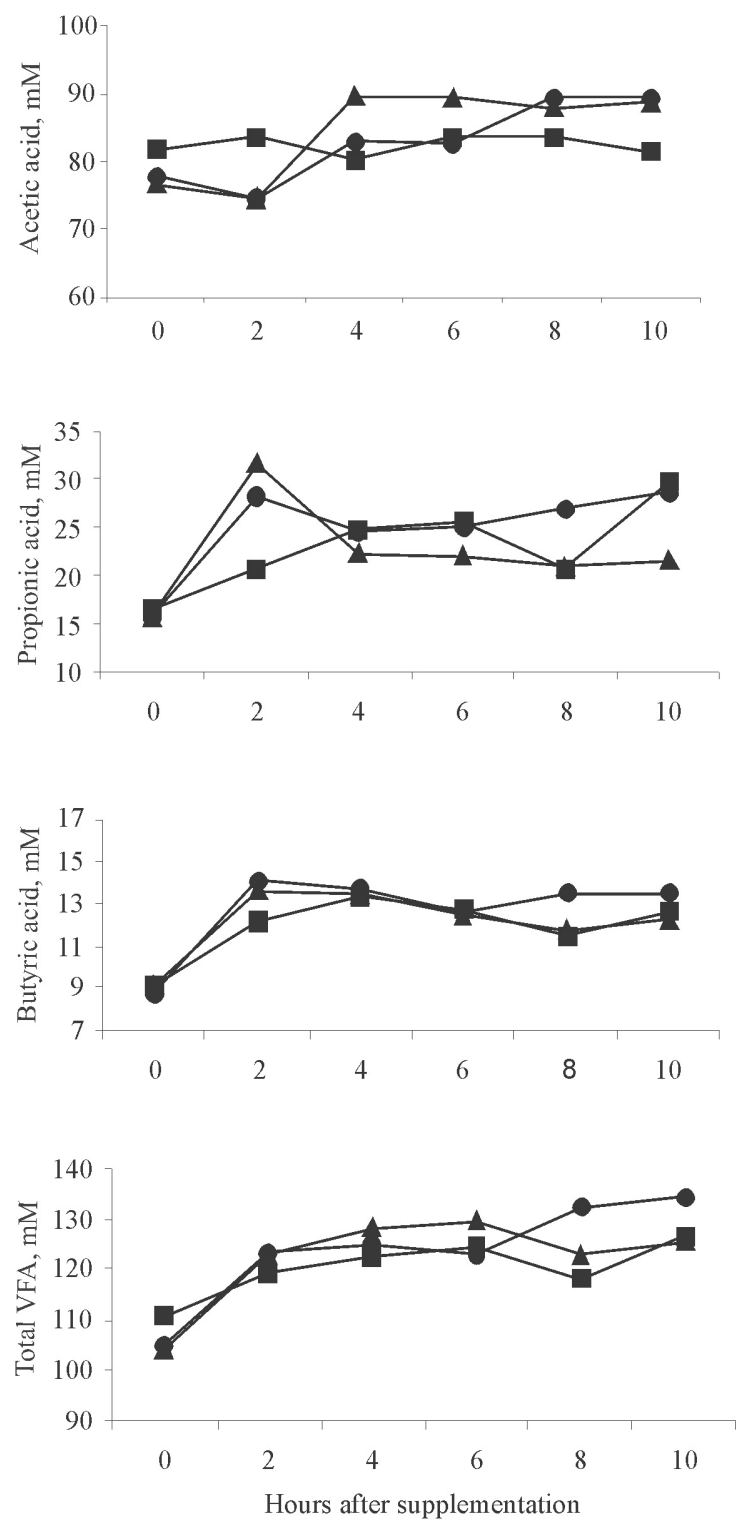

$\neg \mathrm{AD} \rightarrow \mathrm{SS} \rightarrow-\mathrm{OD}$
Day 2
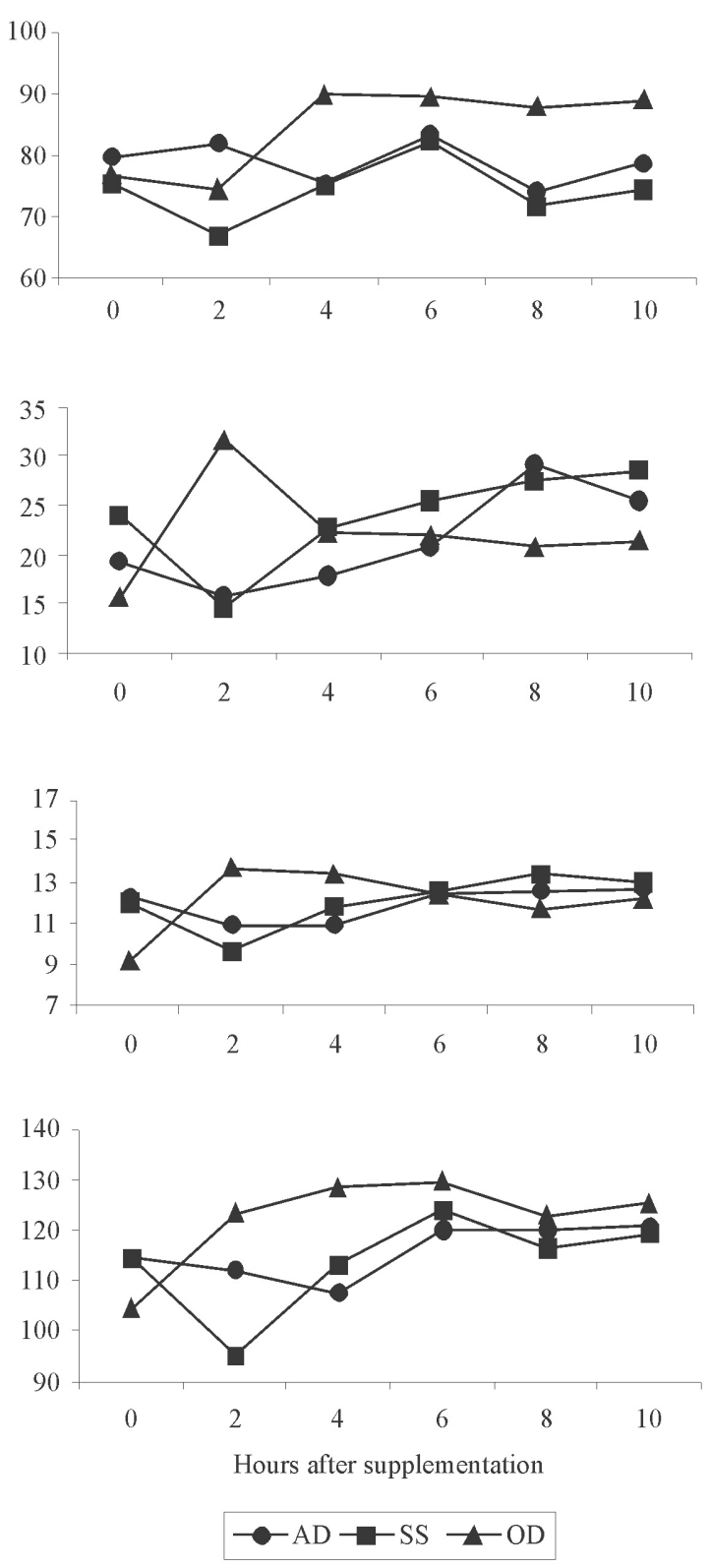

Supplementation frequency: once daily (OD), once daily except Saturdays and Sundays (SS) and on alternate days (AD).

Figure 2 - Effect of supplementation frequency on ruminal concentration of acetic, propionic and butyric acids, and total volatile fatty acids (VFA) on the day all supplements were provided (day 1) and on the day only daily supplements were provided (day 2). 
concentration of acetic acid and total VFA; and effects of the month were noted on all variables. Supplementation frequency $\times$ time interaction $(\mathrm{P}<0.05)$ was not observed only on the total VFA (Figure 2).

Higher ruminal $\mathrm{pH}$ was observed in August (6.34) than in October (6.20). In addition, a supplementation frequency $\times$ time interaction concerning the lower values for $\mathrm{AD}$ supplementation before (time 0 ) or $2 \mathrm{~h}$ and $4 \mathrm{~h}$ after supplementation was observed. The ruminal $\mathrm{N}^{-\mathrm{NH}_{3}}$ content was greater in October $(22.30 \mathrm{mg} \mathrm{dL}-1)$ than in August (17.39 $\mathrm{mg} \mathrm{dL}^{-1}$ ). Additionally, a higher ruminal $\mathrm{NH}_{3}-\mathrm{N}$ content was observed in supplemented animals (OD) $2 \mathrm{~h}$ after supplementation $\left(46.1 \mathrm{mg} \mathrm{dL}^{-1}\right)$ than in nonsupplemented animals (AD and SS) (Figure 1).

Regarding the concentrations of VFA, higher values were observed in October than in August $(\mathrm{P}<0.05)$. The molar concentration of acetic acid was greater for supplemented animals (OD) 4, 8, and $10 \mathrm{~h}$ after supplementation. The same pattern was observed $2 \mathrm{~h}$ after supplementation for propionic acid and 2 and $4 \mathrm{~h}$ after supplementation for the molar concentration of butyric acid and total VFA, indicating a difference between the supplemented and non-supplemented animals in the sampling time (Figure 2). Ruminal fluid volume and dilution rate, $\mathrm{N}$ intake, duodenal bacterial $\mathrm{N}$ flow, and bacterial $\mathrm{N}$ synthesis were not affected by supplementation frequency $(\mathrm{P}>0.05)$ (Table 5). Intake and enteric methane production were not affected by the supplementation frequency $(\mathrm{P}>0.05)$; however, higher values for enteric methane production were obtained in November $(\mathrm{P}<0.05)$ (Table 6).

\section{Discussion}

The results obtained in the present study agree with those found by other authors who also observed that ruminants grazing low-quality forage and supplemented with high-protein supplements showed similar dry matter intake (DMI) between frequencies of supplementation (infrequently or daily) (Canesin et al., 2007; Morais et al., 2009; Canesin et al., 2014; Morais et al., 2014). Krehbiel et al. (1998) showed that DMI and the net portal and hepatic flux of nutrients in mature ewes fed low-quality forage increased in response to supplementation with $80 \mathrm{~g} \mathrm{CP}$ day $^{-1}$ of soybean meal, with no differences observed due to the frequency of supplement administration (once daily or every three days). Additionally, Huston et al. (1999) did not observe significant differences in forage and supplement intake due to supplementation frequency (1x or $3 \mathrm{x}$ per week) in adult Hereford $\times$ Brangus beef cattle in the winter.

The mean $\mathrm{pH}$ values observed in this study are above 6.1-6.4 and never decreased below 6.0 on either the day all supplements were provided or the day only daily supplements were provided. These values are above the

Table 5 - Effect of supplementation frequency on ruminal fluid volume, dilution rate, $\mathrm{N}$ intake, and synthesis of bacterial $\mathrm{N}(\mathrm{n}=9$ )

\begin{tabular}{|c|c|c|c|c|c|}
\hline & \multicolumn{3}{|c|}{ Supplementation frequency } & \multirow{2}{*}{ SEM } & \multirow{2}{*}{ P-value } \\
\hline & $\mathrm{AD}$ & SS & OD & & \\
\hline Ruminal fluid volume, $\mathrm{g} \mathrm{kg}^{-1} \mathrm{BW}$ & 8.82 & 11.16 & 11.25 & 1.35 & 0.38 \\
\hline Ruminal fluid dilution rate, $\mathrm{h}^{-1}$ & 0.126 & 0.113 & 0.107 & 0.84 & 0.29 \\
\hline $\mathrm{N}$ intake, $\mathrm{g}_{\text {day }}{ }^{-1}$ & 70.60 & 94.51 & 81.90 & 8.54 & 0.18 \\
\hline Duodenal $\mathrm{N}$ flow, $\mathrm{g}$ day $^{-1}$ & 77.28 & 89.18 & 77.30 & 12.01 & 0.76 \\
\hline Duodenal bacterial $\mathrm{N}$ flow, $\mathrm{g}_{\text {day }}{ }^{-1}$ & 54.14 & 50.52 & 27.14 & 16.52 & 0.56 \\
\hline Synthesis of bacterial $\mathrm{N}, \mathrm{g}$ of $\mathrm{N} \mathrm{kg}^{-1}$ of OMAD & 13.38 & 14.53 & 6.57 & 4.62 & 0.45 \\
\hline
\end{tabular}

AD - supplementation on alternate days; SS - once daily except Saturdays and Sundays; OD - once daily; SEM - standard error of the mean.

BW - body weight; OMAD - organic matter apparently digested in the rumen.

Table 6 - Effect of the supplementation frequency on steers intake and enteric methane production $\left(\mathrm{CH}_{4}\right)(\mathrm{n}=12)$

\begin{tabular}{|c|c|c|c|c|c|c|c|c|c|}
\hline & \multicolumn{3}{|c|}{ Supplementation frequency } & \multicolumn{2}{|c|}{ Months } & \multirow{2}{*}{ SEM } & \multicolumn{3}{|c|}{ P-value } \\
\hline & $\mathrm{AD}$ & SS & OD & September & November & & SF & M & $\mathrm{SF} \times \mathrm{M}$ \\
\hline DMI, $k g$ day $^{-1}$ & 7.70 & 7.70 & 7.87 & 7.79 & 7.73 & 0.46 & 0.94 & 0.90 & 0.78 \\
\hline GEI, Mcal day ${ }^{-1}$ & 28.53 & 28.59 & 29.26 & 27.60 & 29.98 & 1.43 & 0.92 & 0.17 & 0.79 \\
\hline NDFI, kg day ${ }^{-1}$ & 4.00 & 3.95 & 4.00 & 4.18 & 3.78 & 0.28 & 0.99 & 0.25 & 0.76 \\
\hline $\mathrm{CH}_{4}, \mathrm{~g} \mathrm{day}^{-1}$ & 252.5 & 253.3 & 226.0 & 176.8 & 311.0 & 21.2 & 0.81 & $<0.01$ & 0.96 \\
\hline $\mathrm{CH}_{4}, \mathrm{~g} \mathrm{~kg}^{-1} \mathrm{BW}^{0.75} \mathrm{day}^{-1}$ & 2.81 & 2.31 & 2.45 & 2.08 & 2.97 & 0.59 & 0.38 & 0.01 & 0.64 \\
\hline $\mathrm{CH}_{4}, \mathrm{~g} \mathrm{~kg}^{-1} \mathrm{GEI}$ & 117.3 & 99.4 & 99.7 & 84.5 & 123.4 & 1.14 & 0.38 & 0.01 & 0.89 \\
\hline $\mathrm{CH}_{4}, \mathrm{~g} \mathrm{~kg}^{-1} \mathrm{DMI}$ & 33.37 & 26.90 & 28.42 & 22.81 & 36.32 & 2.99 & 0.38 & $<0.01$ & 0.88 \\
\hline $\mathrm{CH}_{4}, \mathrm{~g} \mathrm{~kg}^{-1} \mathrm{NDFI}$ & 66.24 & 53.51 & 56.45 & 42.86 & 74.60 & 6.42 & 0.44 & $<0.01$ & 0.93 \\
\hline
\end{tabular}

AD - supplementation on alternate days; SS - once daily except Saturdays and Sundays; OD - once daily; SEM - standard error of the mean; SF- supplementation frequency; $\mathrm{M}$ - months; $\mathrm{SF} \times \mathrm{M}$ - supplementation frequency $\times$ month interaction.

DMI - dry matter intake; GEI - gross energy intake; NDFI - neutral detergent fiber intake; BW - body weight. 
range that is considered adequate to maintain fiber digestion and support cellulolytic bacteria, according to Mould et al. (1983). In a similar study, Morais et al. (2009) also noted that the ruminal $\mathrm{pH}$ was not affected by the frequency of supplementation; instead, they measured higher average $\mathrm{pH}$ values - 6.84, with a minimum of 6.5 - in Nellore steers grazing on Marandu grass and supplemented $7 \mathrm{x}, 5 \mathrm{x}$ and $3 \mathrm{x}$ per week. Likewise, Bohnert et al. (2002c), Farmer et al. (2001) and Beaty et al. (1994) found that infrequent supplementation resulted in a lower ruminal $\mathrm{pH}$ compared with daily supplementation when all treated animals received supplementation, but a higher ruminal $\mathrm{pH}$ was observed on the days between supplementation events. In a study of the effects of supplementation frequency on ruminal fermentation in beef steers, Drewnoski and Poore (2012) observed that on the day of supplementation, the ruminal $\mathrm{pH}$ of steers in an alternate-day treatment (6.13) was lower $(\mathrm{P}<0.01)$ than those subjected to the daily-supplementation treatment (6.29). Remarkably, the $\mathrm{pH}$ values remained above 6 even on days when the animals were supplemented infrequently. These animals were also able to maintain a desirable environment for digestion, even on the days they were not supplemented. Notably, providing supplements as infrequently as once every six days appears to be enough to sustain a ruminal environment sufficient to maintain normal fiber digestion.

The $\mathrm{NH}_{3}-\mathrm{N}$ concentrations were similar between the supplementation frequencies, and showed that cattle fed high-protein supplements at non-frequent intervals were able to maintain high levels of ruminal ammonia even on the days when they were not supplemented (Beaty et al., 1994). According to Krehbiel et al. (1998) and Bohnert et al. (2002a), the better efficiency of $\mathrm{N}$ use in infrequently supplemented animals is due to a possible alteration in the permeability of the gastrointestinal tract and/or the regulation of the renal excretion of urea. Evaluating the effect of frequency and the amount of rumen-degradable protein intake on urea kinetics in steers consuming prairie hay, Wickersham et al. (2008) observed that a decreased supplementation level (daily supplementation versus supplementation every three days) resulted in similar urea kinetics between the two supplementation groups.

In a study of supplementation frequencies of cattle consuming a low-quality forage diet, Bohnert et al. (2002c) did not observe significant difference in ruminal fluid volume and dilution rate with degradable-intake protein as supplementation frequency decreased (daily, every 3 or 6 days). In contrast, Farmer et al. (2001) provided degradableintake protein supplement $7 x, 5 x, 3 x$ or $2 x$ per week and reported that fluid passage rate responded quadratically, with the lowest rate occurring on the supplementation provided $2 \mathrm{x}$ per week. The infrequent supplementation of degradable-intake protein may have disrupted rumen function for a period of time, especially in the lower supplementation frequency (Bohnert et al., 2002c).

Likewise, Bohnert et al. (2002b) also not observed significant difference in $\mathrm{N}$ intake, flux of bacterial $\mathrm{N}$, and synthesis of bacterial $\mathrm{N}$ in cattle supplemented daily, three or every six days. The synthesis values of bacterial $\mathrm{N}$ observed by the authors were similar (13.0 $\left.\mathrm{g} \mathrm{N} \mathrm{kg}^{-1} \mathrm{OMAD}\right)$ to values found in this study for AD and SS supplementation. On the other hand, the values of duodenal bacterial $\mathrm{N}$ flow and bacterial $\mathrm{N}$ synthesis were approximately $50 \%$ lower with daily supplementation. Wickersham et al. (2008) found that at the high level of supplementation, recycled urea provided $23 \%$ of the $\mathrm{N}$ in microbial protein for steers supplemented daily, but $42 \%$ for steers supplemented infrequently. Thus, on the days when the infrequently supplemented steers receive the higher level of the degradable-intake protein supplement, rumen-available $\mathrm{N}$ is well in excess of microbial requirements, whereas on the days when they are not supplemented, rumen-available $\mathrm{N}$ is deficient (Titgemeyer, 2012). The author reported that infrequent supplementation leads to much greater amounts of urea recycling, much greater capture of recycled urea-N by ruminal microbes, and a greater proportion of microbial protein being derived from recycled urea. This seems logical because steers supplemented daily are not dependent on urea recycling to meet a large part of the microbes $\mathrm{N}$ needs, whereas the infrequently supplemented animals are very dependent on recycling to provide rumen-available $\mathrm{N}$ for two of three days in the supplementation cycle (Titgemeyer, 2012).

Supplementation frequency had little or no effect on VFA concentrations in comparison with daily supplementation. Similarly, other authors (Farmer et al., 2001; Currier et al., 2004; and Morais et al., 2009) have reported that two-day supplementation intervals (or shorter) had some or no effect on VFA. Morais et al. (2009) observed that ruminal fermentation parameters ( $\mathrm{pH}, \mathrm{NH}_{3}-\mathrm{N}$ and VFA) in Nellore steers on Brachiaria brizantha pastures were stable when supplementation was reduced from seven to five or three times per week; they concluded that the maintenance of these parameters was important for adequate ruminal fermentation. The ruminal VFA by fermentation is directly proportional to feed digestibility, which depends on the composition of the diet and on the feed intake. Therefore, the effect of the month on the VFA concentrations is related to the quality of the available forage, which was optimal in October, with the lowest fiber and highest CP contents compared to August. 
The concentration of total ruminal VFA was higher in October than in August, thus resulting in higher enteric methane production in November because the characteristics of the forage presented in October and November are the same (Table 2). In this case, the highest production of methane is not indicative of the inefficiency of metabolic processes, but rather due to a higher total gas production resulting from the higher quality of forage consumed by the animals. The forage intake was lower in November than in other months, but the nutrient concentration was higher, resulting in a substitutive effect (Table 3 ). Based on the values shown in Table 4, it can be observed that there is a higher ruminal concentration of propionic acid in the month of October if it is assumed that there is a lower production of $\mathrm{CH}_{4}$ because there is an inverse relationship between the production of propionate and the production of $\mathrm{CH}_{4}$.

The values determined for methane production were $176.84 \mathrm{~g} \mathrm{day}^{-1}$ and $310.97 \mathrm{~g} \mathrm{day}^{-1}$ in September and November, respectively. Primavesi et al. (2004b) obtained similar values of methane production in Brazilian crossbred dairy heifers grazing on Brachiaria grass without fertilizer of $181 \mathrm{~g} \mathrm{day}^{-1}$ and $295 \mathrm{~g} \mathrm{day}^{-1}$ in dry cows grazing on Tobiatã grass fertilized in the summer. Methane production in September was $2.08 \mathrm{~g} \mathrm{~kg}^{-1} \mathrm{BW}^{0.75} \mathrm{day}^{-1}$, which agrees with the data reported by Pedreira et al. (2009) for heifers maintained on fertilized and unfertilized pastures $\left(1.9 \mathrm{~g} \mathrm{~kg}^{-1}\right.$ $\mathrm{BW}^{0.75}$ day $^{-1}$ ), but which is lower than the values observed in November $\left(2.1 \mathrm{~g} \mathrm{~kg}^{-1} \mathrm{BW}^{0.75} \mathrm{day}^{-1}\right)$.

The energy loss as methane (Table 6) was high in November (123.4 $\mathrm{g} \mathrm{kg}^{-1} \mathrm{GE}$ intake) and is related to the lower diet intake (Table 3) although there was a high nutrient availability in the forage (Table 2). According to Johnson and Johnson (1995), when highly available carbohydrates are fed at limited intakes, high fractional methane losses occur; in contrast, at high intake levels of highly digestible diets, low fractional methane losses occur. Protein supplementation of low-quality forage will increase methane losses proportionally to the improvement in digestibility. It should be noted, however, that overall methane losses per unit of product (maintenance, lactation, or growth) would decrease with protein supplementation (Johnson and Johnson, 1995).

Kurihara et al. (1999) observed energy losses in cattle fed tropical grasses ( $104 \mathrm{~g} \mathrm{~kg}^{-1} \mathrm{GE}$ intake in Rhodes grass and $114 \mathrm{~g} \mathrm{~kg}^{-1}$ in Engleton grass). Recently, Pelve et al. (2012) observed that methane emissions in non-lactating cows and heifers fed forage harvested from heterogeneous semi-natural pastures corresponded to an average of $89 \mathrm{~g} \mathrm{~kg}^{-1} \mathrm{GE}$ intake. The production of $\mathrm{CH}_{4}$ in $\mathrm{g} \mathrm{kg}^{-1}$ of $\mathrm{DM}$ intake and $\mathrm{g} \mathrm{kg}^{-1}$ of NDF intake was similar $(\mathrm{P}>0.05)$ in animals supplemented daily or less frequently. However, higher values were observed in November, most likely due to the better quality of forage in that month. Pedreira et al. (2009) reported lower values, e.g., $19.1 \mathrm{~g}$ of $\mathrm{CH}_{4} \mathrm{~kg}^{-1}$ of DM intake in heifers maintained on fertilized pastures (intensive system) and $16.0 \mathrm{~g}$ of $\mathrm{CH}_{4} \mathrm{~kg}^{-1}$ of DM intake on pastures without fertilization (extensive system). Thus, we can infer that the lower supplementation frequency did not affect the ruminal fermentation and enteric methane production in cattle grazing on tropical pastures; however, differences were observed in the different seasons (dry and rainy season).

\section{Conclusions}

Although ruminal fermentation characteristics are slightly enhanced by daily supplementation, less frequent supplement administration may be a feasible practice to substantially reduce supplementation costs, with little or no consequences to ruminal fermentation characteristics and enteric methane production.

\section{Acknowledgments}

The authors would like to acknowledge the São Paulo State Research Foundation (FAPESP) for financial support, the National Council of Scientific and Technological Development (CNPq) for granting a PhD scholarship, and the Coordination of Improvement of Higher Education Personnel (CAPES) for granting the International Cooperation Agreement Brazil-Spain scholarship that made the development of the Sandwich Doctoral stage in Spain possible.

\section{References}

AOAC - Association of Oficial Analytical Chemistry. 1990. Oficial methods of analysis. 15th ed. AOAC International, Arlington, VA.

Beaty, J. L.; Cochran, R. C.; Lintzenich, B. A.; Vanzant, E. S.; Morill, J. L.; Brandt, R. T. and Johnson, D. E. 1994. Effect of frequency of supplementation and protein concentration in supplements on performance and digestion characteristics of beef cattle consuming low-quality forages. Journal of Animal Science 72:2475-2486

Bohnert, D. W; Schauer, C. S. and DelCurto, T. 2002a. Influence of rumen protein degradability and supplementation frequency on performance and nitrogen use in ruminants consuming lowquality forage: Cow performance and efficiency of nitrogen use in wethers. Journal of Animal Science 80:1629-1637.

Bohnert, D.W.; Schauer, C. S.; Bauer, M. L. and DelCurto, T. 2002b. Influence of rumen protein degradability and supplementation frequency on steers consuming low-quality forage: I. Site of digestion and microbial efficiency. Journal of Animal Science 80:2967-2977. 
Bohnert, D. W.; Schauer, C. S.; Falck, S. J. and DelCurto, T. 2002c. Influence of rumen protein degradability and supplementation frequency on steers consuming low-quality forage: II. Ruminal fermentation characteristics. Journal of Animal Science 80:2978-2988.

Canesin, R. C.; Berchielli, T. T.; Andrade, P. and Reis, R. A. 2007. Desempenho de bovinos de corte mantidos em pastagem de capimmarandu submetidos a diferentes estratégias de suplementação no período das águas e da seca. Revista Brasileira de Zootecnia 36:411-420.

Canesin, R. C.; Berchielli, T. T.; Vega, A.; Reis, R. A.; Messana, J. D.; Baldi, F. and Pascoa, A. G. 2014. Reducing supplementation frequency for Nellore beef steers grazing tropical pastures. Scientia Agricola 71:105-113.

Cecava, M. J.; Merchen, N. R.; Gay, L. C. and Berber, L. L. 1990. Composition of ruminal bacteria harvested from steers as influenced by dietary energy level, feeding frequency, and isolation techniques. Journal of Dairy Science 73:2480-2488.

Currier, T. A.; Bohnert, D. W.; Falck, S. J. and Bartle, S. J. 2004. Daily and alternate day supplementation of urea or biuret to ruminants consuming low-quality forage: I. Effects on cow performance and the efficiency of nitrogen use in wethers. Journal of Animal Science 82:1508-1517.

Dove, H. and Moore, A. D. 1995. Using a least-square optimization procedure to estimate diet composition based on the alkanes of plant cuticular wax. Australian Journal of Agricultural Research 46:1535-1544.

Dove, H.; Wood, J. T.; Simpson, R. J.; Leury, B. J.; Ciavarella, T. A.; Gatford, K. L. and Siever-Kelly, C. 1999. Spray-topping annual grass pasture with glyphosate todelay loss of feeding value during summer III. Quantitative basis of the alkane based procedures for estimating diet selection and herbage intake by grazing sheep. Australian Journal of Agricultural Research 50:475-485.

Drewnoski, M. E. and Poore, M. H. 2012. Effects of supplementation frequency on ruminal fermentation and digestion by steers fed medium-quality hay and supplemented with soybean hull and corn gluten feed blend. Journal of Animal Science 90:881-891.

Farmer, C. G.; Cochran, R. C.; Simms, D. D.; Klevesahl, E. A.; Wickersham, T. A. and Johnson, D. E. 2001. The effects of several supplementation frequencies on forage use and the performance of beef cattle consuming dormant tallgrass prairie forage. Journal of Animal Science 79:2276-2285.

Farmer, C. G.; Cochran, R. C.; Nagaraja, T. G.; Titgemeyer, E. C.; Johnson, D. E. and Wickersham, T. A. 2004. Ruminal and host adaptations to changes in frequency of protein supplementation. Journal of Animal Science 82:884-894.

Fenner, H. 1965. Method for determining total volatile bases in rumen fluid by steam distillation. Journal of Dairy Science 48:249-251.

Huston, J. E.; Lippke, H.; Forbes, T. D. A.; Holloway, J. W. and Machen, R. V. 1999. Effects of supplemental feeding interval on adult cows in Western Texas. Journal of Animal Science 77:3057-3067.

Johnson, K. A and Johnson, D. E. 1995. Methane emissions from cattle. Journal of Animal Science 73:2483-2492.

Keli, A.; Andueza, D.; de Veja, A. and Guada, J. A. 2008. Validation of the n-alkane and NIRS techniques to estimate intake, digestibility and diet composition in sheep fed mixed lucerne: ryegrass diets. Livestock Science 119:42-54.

Krehbiel, C. R.; Ferrell, C. L. and Freetly, H. C. 1998. Effects of frequency of supplementation on dry matter intake and net portal and hepatic flux of nutrients in mature ewes that consume lowquality forage. Journal of Animal Science 76:2464-2473.

Kurihara, M.; Magner, T.; Hunter, R. A. and Mccrabb, G. J. 1999. Methane production and energy partition of cattle in the tropics. British Journal of Nutrition 81:227-234.
Mayes, R. W.; Lamb, C. S. and Colgrove, P. M. 1986. The use of dosed and herbage n-alkanes as markers for the determination of herbage intake. Journal of Agricultural Science 107:161-170.

Mertens, D. R. 2002. Gravimetric determination of amylase-treated neutral detergent fiber in feeds with refluxing in beakers or crucibles: collaborative study. Journal of AOAC International 85:1217-1240.

Morais, J. A. S.; Berchielli, T. T.; Queiroz, M. F. S.; Keli, A.; Reis, R. A. and Souza, S. F. 2009. Influência da frequência de suplementação no consumo, na digestibilidade e na fermentação ruminal em novilhos de corte mantidos em pastagem de capimmarandu. Revista Brasileira de Zootecnia 38:1824-1834.

Morais, J. A. S.; Queiroz, M. F. S.; Keli, A.; Vega, A.; Fiorentini, G.; Canesin, R. C.; Reis, R. A. and Berchielli, T. T. 2014. Effect of supplementation frequency on intake, behavior and performance in beef steers grazing Marandu grass. Animal Feed Science and Technology 189:63-71.

Moss, A. R. 1994. Methane production by ruminants - literature review of I. Dietary manipulation to reduce production and II. Laboratory procedure for estimating methane potential of diets. Nutrition Abstracts and Reviews 64:785-806.

Mould, F. L.; Ørskov, E. R and Mann, S. O. 1983. Associative effects of mixed feeds. I. Effects of type and level of supplementation and the influence of the rumen fluid $\mathrm{pH}$ on cellulolysis in vivo and dry matter digestion of various roughages. Animal Feed Science and Technology 10:15-30.

NRC - Nutrient requirements of beef cattle. 1984. 6th ed. National Academy Press, Washington, DC.

Palmquist, D. L. and Conrad, H. 1971. Origin of plasma fatty acids in lactating cows fed high fat diets. Journal of Dairy Science 54:1025-1033.

Pedreira, M. S.; Primavesi, O.; Lima, M. A.; Frighetto, R.; Oliveira, S. G. and Berchielli, T. T. 2009. Ruminal methane emission by dairy cattle in southeast Brazil. Scientia Agricola 66:742-750.

Pelve, M. E.; Olsson, I.; Spörndly, E. and Eriksson, T. 2012. In vivo and in vitro digestibility, nitrogen balance and methane production in non-lactating cows and heifers fed forage harvested from heterogeneous semi-natural pastures. Livestock Science 144:48-56.

Primavesi, O.; Frigheto, R. T. S.; Pedreira, M. S.; Lima, M. A.; Berchielli, T. T.; Demarchi, J. J. A. A.; Manella, M. Q.; Barbosa, P. F.; Johnson, K. A. and Westberg, H. H. 2004a. SF -tracer technique for bovine ruminal methane field measurents: adaptations to Brazilian conditions. Embrapa Pecuária Sudeste, São Carlos. (Documento, 39).

Primavesi, O.; Frighetto, R. T.; Pedreira, M. S.; Lima, M. A.; Berchielli, T. T. and Barbosa, P. F. 2004b. Metano entérico de bovinos leiteiros em condições tropicais brasileiras. Pesquisa Agropecuária Brasileira 39:277-283.

Senger, C. C. D.; Kozloski, G. V.; Sanchez, L. M. B.; Mesquita, F. R.; Alves, T. P. and Castagnino, D. S. 2008. Evaluation of autoclave procedures for fiber analysis in forage and concentrate feedstuffs. Animal Feed Science and Technology 146:169-174.

Titgemeyer, E. C. 2012. Importance of nitrogen recycling to beef cattle grazing low-protein forages. In: Proceedings of the 23rd Annual Florida Ruminant Nutrition Symposium. University of Florida, Gainesville, Florida.

Udén, P.; Colucci, P. E. and Van Soest, P. J. 1980. Investigation of chromium, cerium, and cobalt as markers in digesta. Rate of passage studies. Journal of the Science of Food and Agriculture 31:625-632.

Ushida, K.; Lassalas, B. and Jouany, J. P. 1985. Determination of assay parameters for RNA analysis in bacterial and duodenal samples by spectrophotometry. Influence of sample treatment and preservation. Reproduction Nutrition Development 25:1037-1046. 
Van Soest, P. J. and Robertson, J. B. 1985. Analysis of forages and fibrous foods. Cornell University, Ithaca.

Warner, A. C. I. and Stacy, B. D. 1968. The fate of water in the rumen. I. A critical appraisal of the use of soluble markers. British Journal of Nutrition 22:369-387.

Westberg, H. H.; Johnson, K. A. and Cossalman, M. W. 1998. SF 6 tracer technique: methane measurement from ruminants. Report, Revision 2. Washington State University, Pullman, Washington, U.S.
Wickersham, T. A.; Titgemeyer, E. C.; Cochran, R. C.; Wickersham, E. E. and Moore, E. S. 2008. Effect of frequency and amount of rumen-degradable intake protein supplementation on urea kinetics and microbial use of recycled urea in steers consuming low-quality forage. Journal of Animal Science 86:3089-3099.

Zinn, R. A. and Owens, E. N. 1986. A rapid procedure for purine measurement and its use for estimating net ruminal protein synthesis. Canadian Journal of Animal Science 66:157-166. 